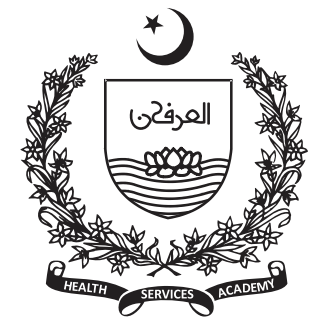

${ }^{1}$ Assistant Professor Forensic Medicine Department, Federal Medical \& Dental College, Islamabad, Pakistan

2 Associate Professor Community Medicine Department, Federal Medical \& Dental College, Islamabad, Pakistan

${ }^{3}$ Demonstrator Community Medicine Department, Federal Medical \& Dental College, Islamabad, Pakistan

${ }^{4}$ Federal Medical \& Dental College, Islamabad, Pakistan

${ }^{5}$ Frontier Medical \& Dental College, Abbottabad, Pakistan.

Corresponding Author: Nadia Junaid

Email:

nadiajunaid313@gmail.com

\section{Trend of Medical Research Journal and Article Reading among Medical Students - An Experimental Approach}

\author{
Ayesha Haider1, Zafar Hayat Maken², Nadia Junaid³, Agha Syed Ali \\ Haider Naqvi ${ }^{4}$, Muhammad Haris Ramzan, ${ }^{4}$ Syeda Zuha Naqvi5, Umar \\ Mustafa4, Muhammad Abdul Basit ${ }^{4}$
}

\section{Abstract}

Background: We conducted this study to assess the knowledge, attitude and practice of medical research journals and article reading among medical students, to point out factors contributing to perceived barriers towards this activity and to investigate the effect of research seminars, workshops, motivation and mentorship of medical students.

Methods: A medical college based experimental study was carried out in two phases, in which second, third- and fourth-year medical students attending the lectures of community medicine were enrolled. A well-structured questionnaire was used to assess the attitude of students, towards research-based activities. Based on the results, the students who showed lack of interest towards research were divided into two groups, experimental and control for the second phase of the study and were subjected to the final questionnaire, the results were then recorded and the data was analyzed using statistical techniques.

Results: 226 students recruited for the first part of the study, showed lack of motivation, guidance, mentorship, and curriculum overload as significant factors affecting their research activities. Whereas in second part of the study, the experimental group showed an increase of $23-35 \%$ in research activities after research mentorship programs as compared to the control group.

Conclusion: The proper understanding of research was generally low among medical students. Lack of motivation, mentorship, and curriculum overload were among the leading factors affecting their attitude towards research. The motivational lectures, and mentorship programs proved very successful in improving student's knowledge about research and research-based activities

Keywords: Perceived barriers; medical students; seminars; workshops; mentorship 


\section{Introduction}

$\mathrm{R}$ esearch is any creative systematic activity undertaken to increase the stock of knowledge, including knowledge of man, culture and society, and the use of this knowledge to devise new applications. (1) Whereas a research article reports the results of original research, assesses its contribution to the body of knowledge in a given area, and is published in a peer-reviewed scholarly journal $(2,3,4,5)$

Medical research is important as it keeps medical students in touch with the latest advances in science and medicine. When medical scientists, researchers or field experts have an experiment or information to add to the body of knowledge in their field of medicine, they usually write up their findings for inclusion in a medical journal. The whole purpose of writing a research article and publishing it in a journal is to provide updated and advanced knowledge in this particular field. In such a case if the students do not read them and do not benefit from the knowledge provided by these journals, then what is the use of doing Research? Students do not spend ample time in reading research journals and articles leading to lack of knowledge and interest in research and research-based activities. $(6,7,8,9)$

As a part of research, conducted at King Edward Medical University, it was found that most of the students showed lack of interest in Research .Factors contributing to lack of interest were , most of students think research as useless activity, lack of internet facilities, time limitation, curriculum overload, lack of counselling, lack of knowledge and motivation, and uncooperative staff. (6) A recent study carried out at The Children's Hospital and The Institute of Child Health (ICH) Lahore, Pakistan showed lack of proper training for research and lack of previous exposure to research which shows that knowledge and understanding of research is necessary and essential otherwise it can be a barrier in future research activities.(7) Another study conducted at three medical schools (Queens University, University of Ottawa and University of Western Ontario) showed lack of interest among students towards research. (8) The same results were depicted by a study conducted at Saudi Arabia by Khalid M. Al Ghamdi with lack of training courses and lack of professional supervisors for research as the main obstacles. (9)
Though students of Pakistan are keen and have positive attitude towards knowledge and their studies but they are unable to show much progress in the field of medical research due to multiple factors. As studies have shown that undergraduate students of Pakistan have to face many obstacles to conduct research or read medical journals or any research activity, including lack of internet facilities, research knowledge etc., unavailability of funds, mentors and time management issues due to burden of studies. $(6,7)$ Hence, there is a need to investigate the leading factors affecting the student's research activities such as medical journal reading, and conducting research. Therefore, the main purpose of this study was to assess the attitude and practice of medical research journals and article reading among medical students of Federal Medical \& Dental College, to identify the factors contributing to the perceived barriers towards this activity, and to assess the impact of research educational programs i.e., research seminars, workshops, motivational lectures and mentorship on medical students.

\section{Methodology}

This study was performed from January 2019 to July 2019 on second year, third year and fourth year MBBS Students. Ethical clearance for this study was received from the ethical review board of Shaheed Zulfiqar Ali Bhutto Medical University Islamabad, Pakistan. This was an institution-based experimental study with the purpose to investigate the impact of research seminars, workshops, motivational lectures, and mentorship on the medical students. Study site was Federal Medical \& Dental College, Pakistan.

Federal Medical \& Dental College is a Public Sector Medical institution located in the Islamabad Capital Territory, Pakistan, with students coming from all the provinces of country. Although research is an important component for all medical students, the medical institutions of Pakistan have made it a mandatory component for only the fourth year.

In first phase of this study, 226 students attending the lectures of community medicine in second, third and fourth year, were enrolled and included in our study population. The study population was assessed for various factors contributing to their interest and attitude towards research activities. A well-structured, self-developed and self-administered questionnaire was used. Based on the results, along with the further 
discussion and help of the community medicine department, the students who showed lack of interest towards research were divided into two groups, experimental and control and were subjected to the final questionnaire.

A sample size of 152 students met the objectives for the second phase of this study. The experimental group was therefore defined as any second, third or fourth year medical student who showed lack of interest towards research. The experimental group was then made to attend different research workshops, seminars and motivational lectures by research speakers and mentors. However, a control was defined as any second, third or fourth year medical student who showed lack of interest towards research. They were not made a subject of any such activity. All other students of the medical institute, official staff and teaching staff were excluded from the study.

\section{Data collection and analysis}

An interview date was decided to gather information from the control and experimental group using a pretested, structured, and self-administered questionnaire after the seminars and motivational lectures.

The data collection and analysis process were closely supervised by the faculty of the Community Medicine department, who reviewed the questionnaires after complete data collection. Data was analyzed using IBM SPSS (Statistical Package for Social Sciences) Statistics 25.0 software. In statistical analysis of the results, a P-value of $\leq 0.05$ was considered significant.

\section{Results}

226 students $\left(76\right.$ from $2^{\text {nd }}$ Year, 82 from $3^{\text {rd }}$ Year \& 68 from $4^{\text {th }}$ Year) were recruited for the first part of the study and were assessed for different factors contributing to their interest towards research. The results showed that majority of the students showed lack of interest towards research and research based studies (152 students) whereas lack of motivation $(74.78 \%)$, guidance $(82.74 \%)$, mentorship $(72.12 \%)$ and curriculum overload $(69.91 \%)$ were significant factors affecting their research activities (Table 1).

Table 1: Shows possible factors that are responsible for interest in medical research journals and article reading among medical students and their attitude towards research.

\begin{tabular}{|c|c|c|c|c|c|c|c|c|}
\hline & \multicolumn{2}{|c|}{ 2ND YEAR $^{\text {ND }}$} & \multicolumn{2}{|c|}{$3^{\text {RD }}$ YEAR } & \multicolumn{2}{|c|}{$4^{\text {TH }}$ YEAR } & \multicolumn{2}{|c|}{ TOTAL } \\
\hline VARIABLES & $\mathrm{n}$ & $\%$ & $\mathrm{~N}$ & $\%$ & $\mathrm{~N}$ & $\%$ & $\mathrm{~N}$ & $\%$ \\
\hline \multicolumn{9}{|c|}{1 - Do you know what a Medical Journal is? } \\
\hline $\begin{array}{ll}\text { - } & \text { Yes } \\
\text { - } & \text { No }\end{array}$ & $\begin{array}{l}29 \\
47\end{array}$ & $\begin{array}{l}38.16 \\
61.84\end{array}$ & $\begin{array}{l}38 \\
44\end{array}$ & $\begin{array}{l}46.34 \\
53.66\end{array}$ & $\begin{array}{l}47 \\
21\end{array}$ & $\begin{array}{l}69.12 \\
30.88\end{array}$ & $\begin{array}{l}114 \\
112\end{array}$ & $\begin{array}{l}50.44 \\
49.56\end{array}$ \\
\hline \multicolumn{9}{|c|}{2 - Do you know what a Research Article is? } \\
\hline $\begin{array}{ll}\text { - } & \text { Yes } \\
\text { - No }\end{array}$ & $\begin{array}{l}33 \\
43 \\
\end{array}$ & $\begin{array}{l}43.42 \\
56.58\end{array}$ & $\begin{array}{l}41 \\
41 \\
\end{array}$ & $\begin{array}{l}50 \\
50\end{array}$ & $\begin{array}{l}49 \\
19 \\
\end{array}$ & $\begin{array}{l}72.06 \\
27.94 \\
\end{array}$ & $\begin{array}{l}123 \\
103 \\
\end{array}$ & $\begin{array}{l}54.42 \\
45.58 \\
\end{array}$ \\
\hline \multicolumn{9}{|c|}{3 - Have you ever seen a journal in your college or library? } \\
\hline $\begin{array}{ll}\text { - } & \text { Yes } \\
\text { - } & \text { No } \\
\end{array}$ & $\begin{array}{l}28 \\
48 \\
\end{array}$ & $\begin{array}{l}36.84 \\
63.16 \\
\end{array}$ & $\begin{array}{l}36 \\
46 \\
\end{array}$ & $\begin{array}{l}43.9 \\
56.1 \\
\end{array}$ & $\begin{array}{l}37 \\
31 \\
\end{array}$ & $\begin{array}{l}54.41 \\
45.59 \\
\end{array}$ & $\begin{array}{l}101 \\
125 \\
\end{array}$ & $\begin{array}{l}44.69 \\
55.31 \\
\end{array}$ \\
\hline \multicolumn{9}{|c|}{4 - If yes, then did you ever read any medical journal in your medical life? } \\
\hline $\begin{array}{ll}\text { - } & \text { Yes } \\
\text { - } & \text { No } \\
\end{array}$ & $\begin{array}{c}9 \\
67 \\
\end{array}$ & $\begin{array}{l}11.84 \\
88.16 \\
\end{array}$ & $\begin{array}{l}11 \\
71\end{array}$ & $\begin{array}{l}13.41 \\
86.59\end{array}$ & $\begin{array}{l}25 \\
43 \\
\end{array}$ & $\begin{array}{l}36.76 \\
63.24 \\
\end{array}$ & $\begin{array}{c}45 \\
181\end{array}$ & $\begin{array}{l}19.91 \\
80.09\end{array}$ \\
\hline \multicolumn{9}{|c|}{5 - Did you ever read a research article in your medical life? } \\
\hline $\begin{array}{ll}\text { - } & \text { Yes } \\
\text { - } & \text { No }\end{array}$ & $\begin{array}{l}15 \\
61 \\
\end{array}$ & $\begin{array}{l}19.74 \\
80.26\end{array}$ & $\begin{array}{l}19 \\
63 \\
\end{array}$ & $\begin{array}{l}23.17 \\
76.83\end{array}$ & $\begin{array}{l}31 \\
37 \\
\end{array}$ & $\begin{array}{l}45.59 \\
54.41\end{array}$ & $\begin{array}{c}65 \\
161 \\
\end{array}$ & $\begin{array}{l}28.76 \\
71.24 \\
\end{array}$ \\
\hline \multicolumn{9}{|c|}{6 - Reading research journals and articles is a waste of time? } \\
\hline - Yes & & & & & & & & \\
\hline
\end{tabular}




\begin{tabular}{|c|c|c|c|c|c|c|c|c|}
\hline - $\quad$ No & $\begin{array}{l}52 \\
24\end{array}$ & $\begin{array}{l}68.42 \\
31.58\end{array}$ & $\begin{array}{l}54 \\
28\end{array}$ & $\begin{array}{l}65.85 \\
34.15\end{array}$ & $\begin{array}{l}42 \\
26\end{array}$ & $\begin{array}{l}61.76 \\
38.24\end{array}$ & $\begin{array}{c}148 \\
78\end{array}$ & $\begin{array}{l}65.49 \\
34.51\end{array}$ \\
\hline \multicolumn{9}{|c|}{7 - Research is useless? } \\
\hline $\begin{array}{ll}\text { - } & \text { Yes } \\
\text { - } & \text { No }\end{array}$ & $\begin{array}{l}51 \\
25\end{array}$ & $\begin{array}{l}67.11 \\
32.89\end{array}$ & $\begin{array}{l}51 \\
31\end{array}$ & $\begin{array}{l}62.2 \\
37.8\end{array}$ & $\begin{array}{l}43 \\
25\end{array}$ & $\begin{array}{l}63.24 \\
36.76\end{array}$ & $\begin{array}{c}145 \\
81\end{array}$ & $\begin{array}{l}64.16 \\
35.84\end{array}$ \\
\hline \multicolumn{9}{|c|}{8 - I find this activity boring? } \\
\hline $\begin{array}{ll}\text { - } & \text { Yes } \\
\text { - } & \text { No }\end{array}$ & $\begin{array}{l}59 \\
17\end{array}$ & $\begin{array}{l}77.63 \\
22.37\end{array}$ & $\begin{array}{l}57 \\
25\end{array}$ & $\begin{array}{l}69.51 \\
30.49\end{array}$ & $\begin{array}{l}48 \\
20\end{array}$ & $\begin{array}{l}70.59 \\
29.41\end{array}$ & $\begin{array}{c}164 \\
62\end{array}$ & $\begin{array}{l}72.57 \\
27.43\end{array}$ \\
\hline \multicolumn{9}{|c|}{9 -Is Curriculum overload / Excessive syllabus a reason for not participating in research activities? } \\
\hline $\begin{array}{ll}\text { - } & \text { Yes } \\
\text { - } & \text { No }\end{array}$ & $\begin{array}{l}52 \\
24\end{array}$ & $\begin{array}{l}68.42 \\
31.58\end{array}$ & $\begin{array}{l}63 \\
19\end{array}$ & $\begin{array}{l}76.83 \\
23.17\end{array}$ & $\begin{array}{l}43 \\
25\end{array}$ & $\begin{array}{l}63.24 \\
36.76\end{array}$ & $\begin{array}{c}158 \\
68\end{array}$ & $\begin{array}{l}69.91 \\
30.09\end{array}$ \\
\hline \multicolumn{9}{|c|}{10 - You prefer extra-curricular activities over this. } \\
\hline $\begin{array}{ll}\text { - } & \text { Yes } \\
\text { - } & \text { No } \\
\end{array}$ & $\begin{array}{l}49 \\
27 \\
\end{array}$ & $\begin{array}{l}64.47 \\
35.53 \\
\end{array}$ & $\begin{array}{l}56 \\
26 \\
\end{array}$ & $\begin{array}{l}68.29 \\
31.71 \\
\end{array}$ & $\begin{array}{l}50 \\
18 \\
\end{array}$ & $\begin{array}{l}73.53 \\
26.47 \\
\end{array}$ & $\begin{array}{c}155 \\
71 \\
\end{array}$ & $\begin{array}{l}68.58 \\
31.42 \\
\end{array}$ \\
\hline \multicolumn{9}{|c|}{11 - Reading novels and watching movies is better than reading medical journals \& articles. } \\
\hline $\begin{array}{ll}\text { - } & \text { Yes } \\
\text { - } & \text { No } \\
\end{array}$ & $\begin{array}{l}51 \\
25 \\
\end{array}$ & $\begin{array}{l}67.11 \\
32.89 \\
\end{array}$ & $\begin{array}{l}60 \\
22 \\
\end{array}$ & $\begin{array}{l}73.17 \\
26.83 \\
\end{array}$ & $\begin{array}{l}41 \\
27 \\
\end{array}$ & $\begin{array}{l}60.29 \\
39.71 \\
\end{array}$ & $\begin{array}{c}152 \\
74 \\
\end{array}$ & $\begin{array}{l}67.26 \\
32.74 \\
\end{array}$ \\
\hline \multicolumn{9}{|c|}{12 - Lack of internet facility and Internet inexperience. } \\
\hline $\begin{array}{ll}\text { - } & \text { Yes } \\
\text { - } & \text { No }\end{array}$ & $\begin{array}{l}37 \\
39\end{array}$ & $\begin{array}{l}48.68 \\
51.32\end{array}$ & $\begin{array}{l}25 \\
57\end{array}$ & $\begin{array}{l}30.49 \\
69.51\end{array}$ & $\begin{array}{l}22 \\
46\end{array}$ & $\begin{array}{l}32.35 \\
67.65\end{array}$ & $\begin{array}{c}84 \\
142\end{array}$ & $\begin{array}{l}37.17 \\
62.83\end{array}$ \\
\hline \multicolumn{9}{|c|}{13 - Unsupportive colleagues? } \\
\hline $\begin{array}{ll}\text { - } & \text { Yes } \\
\text { - } & \text { No } \\
\end{array}$ & $\begin{array}{c}69 \\
7 \\
\end{array}$ & $\begin{array}{c}90.79 \\
9.21 \\
\end{array}$ & $\begin{array}{l}60 \\
22 \\
\end{array}$ & $\begin{array}{l}73.17 \\
26.83 \\
\end{array}$ & $\begin{array}{l}39 \\
29 \\
\end{array}$ & $\begin{array}{l}57.35 \\
42.65 \\
\end{array}$ & $\begin{array}{c}168 \\
58 \\
\end{array}$ & $\begin{array}{l}74.34 \\
25.66 \\
\end{array}$ \\
\hline \multicolumn{9}{|c|}{14 - Finding a mentor? } \\
\hline $\begin{array}{ll}\text { - } & \text { Yes } \\
\text { - } & \text { No } \\
\end{array}$ & $\begin{array}{l}62 \\
14 \\
\end{array}$ & $\begin{array}{l}81.58 \\
18.42\end{array}$ & $\begin{array}{l}53 \\
29\end{array}$ & $\begin{array}{l}64.63 \\
35.37\end{array}$ & $\begin{array}{l}48 \\
20\end{array}$ & $\begin{array}{l}70.59 \\
29.41\end{array}$ & $\begin{array}{c}163 \\
63\end{array}$ & $\begin{array}{l}72.12 \\
27.88\end{array}$ \\
\hline \multicolumn{9}{|c|}{15 - Busy Schedule? } \\
\hline $\begin{array}{ll}\text { - } & \text { Yes } \\
\text { - } & \text { No } \\
\end{array}$ & $\begin{array}{l}53 \\
23 \\
\end{array}$ & $\begin{array}{l}69.74 \\
30.26 \\
\end{array}$ & $\begin{array}{l}48 \\
34 \\
\end{array}$ & $\begin{array}{l}58.54 \\
41.46\end{array}$ & $\begin{array}{l}45 \\
23 \\
\end{array}$ & $\begin{array}{l}66.18 \\
33.82 \\
\end{array}$ & $\begin{array}{c}146 \\
80 \\
\end{array}$ & $\begin{array}{l}64.6 \\
35.4 \\
\end{array}$ \\
\hline \multicolumn{9}{|c|}{16 - Lack of encouragement or motivation? } \\
\hline $\begin{array}{ll}\text { - } & \text { Yes } \\
\text { - } & \text { No }\end{array}$ & $\begin{array}{l}61 \\
15 \\
\end{array}$ & $\begin{array}{l}80.26 \\
19.74 \\
\end{array}$ & $\begin{array}{l}60 \\
22 \\
\end{array}$ & $\begin{array}{l}73.17 \\
26.83\end{array}$ & $\begin{array}{l}48 \\
20 \\
\end{array}$ & $\begin{array}{l}70.59 \\
29.41 \\
\end{array}$ & $\begin{array}{c}169 \\
57\end{array}$ & $\begin{array}{l}74.78 \\
25.22 \\
\end{array}$ \\
\hline \multicolumn{9}{|c|}{17 - Lack of guidance from teachers/professors? } \\
\hline $\begin{array}{ll}\text { - } & \text { Yes } \\
\text { - } & \text { No } \\
\end{array}$ & $\begin{array}{l}65 \\
11 \\
\end{array}$ & $\begin{array}{l}85.53 \\
14.47 \\
\end{array}$ & $\begin{array}{l}66 \\
16 \\
\end{array}$ & $\begin{array}{l}80.49 \\
19.51 \\
\end{array}$ & $\begin{array}{l}56 \\
12 \\
\end{array}$ & $\begin{array}{l}82.35 \\
17.65 \\
\end{array}$ & $\begin{array}{c}187 \\
39 \\
\end{array}$ & $\begin{array}{l}82.74 \\
17.26 \\
\end{array}$ \\
\hline 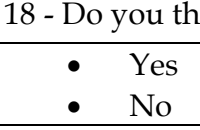 & $\begin{array}{l}\text { rese } \\
41 \\
35 \\
\end{array}$ & $\begin{array}{c}\text { urnals \& } \\
53.95 \\
46.05 \\
\end{array}$ & $\begin{array}{l}\text { es an } \\
45 \\
37 \\
\end{array}$ & $\begin{array}{l}\text { resea1 } \\
54.88 \\
45.12 \\
\end{array}$ & $\begin{array}{l}\mathrm{k} \text { is } 1 \\
28 \\
40\end{array}$ & $\begin{array}{c}\text { ortant } \\
41.18 \\
58.82 \\
\end{array}$ & $\begin{array}{l}\text { g a m } \\
114 \\
112 \\
\end{array}$ & $\begin{array}{l}50.44 \\
49.56 \\
\end{array}$ \\
\hline
\end{tabular}


In second part of the study, the experimental group showed an increase in interest towards research and research based activities. The interest of the students increased by $23 \%-35 \%$ and the number of students considering medical journal reading, and research useless and boring decreased by $34 \%$ as compared to the control group. The Chi-square test value was found to be 86.492 . The $\mathrm{P}$ value was found to be significant $(\mathrm{p}<0.001)$ (Table 2).

Table 2: Shows the comparison between the experimental and control group after phase 2 of the study.

\begin{tabular}{|c|c|c|c|c|}
\hline \multirow[b]{2}{*}{ VARIABLES } & \multicolumn{2}{|c|}{$\begin{array}{l}\text { TOTAL STUDENTS FOR } \\
\text { EXPERIMENTAL GROUP }=76\end{array}$} & \multicolumn{2}{|c|}{$\begin{array}{l}\text { TOTAL STUDENTS FOR CONTROL GROUP }= \\
76\end{array}$} \\
\hline & $\mathrm{N}$ & $\%$ & $\mathrm{~N}$ & $\%$ \\
\hline $\begin{array}{l}\text { Reading research journals } \\
\text { and articles is a waste of } \\
\text { time } \\
\begin{array}{l}\text { - Yes } \\
\text { - No }\end{array}\end{array}$ & $\begin{array}{l}32 \\
44\end{array}$ & $\begin{array}{l}42.11 \\
57.89\end{array}$ & $\begin{array}{l}60 \\
16\end{array}$ & $\begin{array}{l}78.95 \\
21.05\end{array}$ \\
\hline $\begin{array}{c}\text { Research is useless } \\
\text { - Yes } \\
\text { - No }\end{array}$ & $\begin{array}{l}30 \\
46\end{array}$ & $\begin{array}{l}39.47 \\
60.53\end{array}$ & $\begin{array}{l}59 \\
17\end{array}$ & $\begin{array}{l}77.63 \\
22.37\end{array}$ \\
\hline $\begin{array}{l}\text { I find this activity boring } \\
\begin{array}{c}\text { - Yes } \\
\text { - No }\end{array}\end{array}$ & $\begin{array}{l}39 \\
37\end{array}$ & $\begin{array}{l}51.32 \\
48.68\end{array}$ & $\begin{array}{l}66 \\
10\end{array}$ & $\begin{array}{l}86.84 \\
13.16\end{array}$ \\
\hline $\begin{array}{l}\text { You prefer extra-curricular } \\
\text { activities over this } \\
\text { - Yes } \\
\text { - No }\end{array}$ & $\begin{array}{l}39 \\
37\end{array}$ & $\begin{array}{l}51.32 \\
48.68\end{array}$ & $\begin{array}{c}67 \\
9\end{array}$ & $\begin{array}{l}88.16 \\
11.84\end{array}$ \\
\hline $\begin{array}{l}\text { Reading novels and } \\
\text { watching movies is better } \\
\text { than reading medical } \\
\text { journals \& articles } \\
\text { - Yes } \\
\text { - No }\end{array}$ & $\begin{array}{l}40 \\
36\end{array}$ & $\begin{array}{l}52.63 \\
47.37\end{array}$ & $\begin{array}{c}68 \\
8\end{array}$ & $\begin{array}{l}89.47 \\
10.53\end{array}$ \\
\hline $\begin{array}{l}\text { Do you think reading } \\
\text { research journals \& articles } \\
\text { and doing research work is } \\
\text { not important as being a } \\
\text { medical student? } \\
\text { - Yes } \\
\text { - No }\end{array}$ & $\begin{array}{l}20 \\
56\end{array}$ & $\begin{array}{l}26.32 \\
73.68\end{array}$ & $\begin{array}{l}58 \\
18\end{array}$ & $\begin{array}{l}76.32 \\
23.68\end{array}$ \\
\hline
\end{tabular}




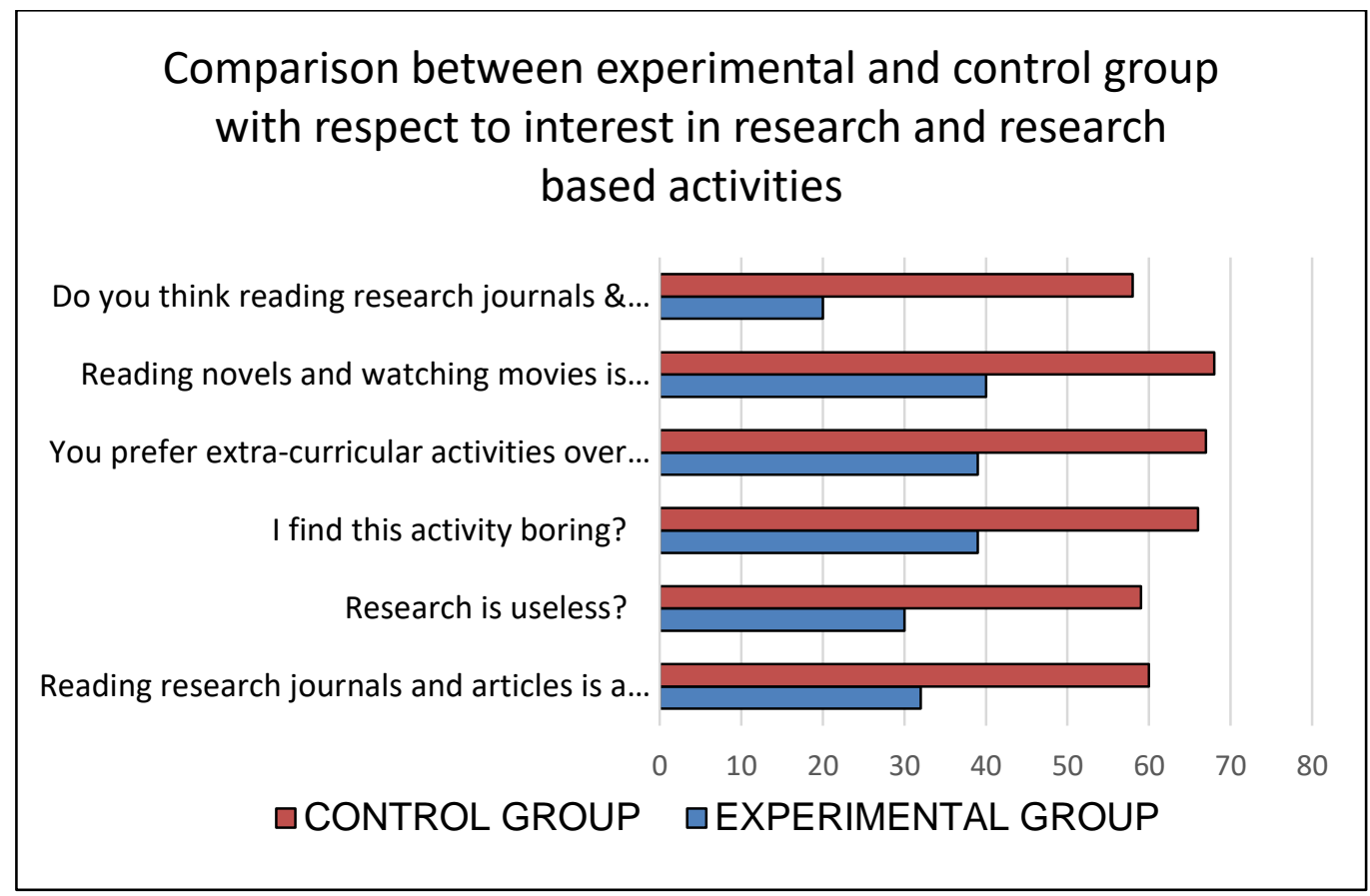

Figure 1. Comparison between experimental and control group with respect to interest in research and research based activities.

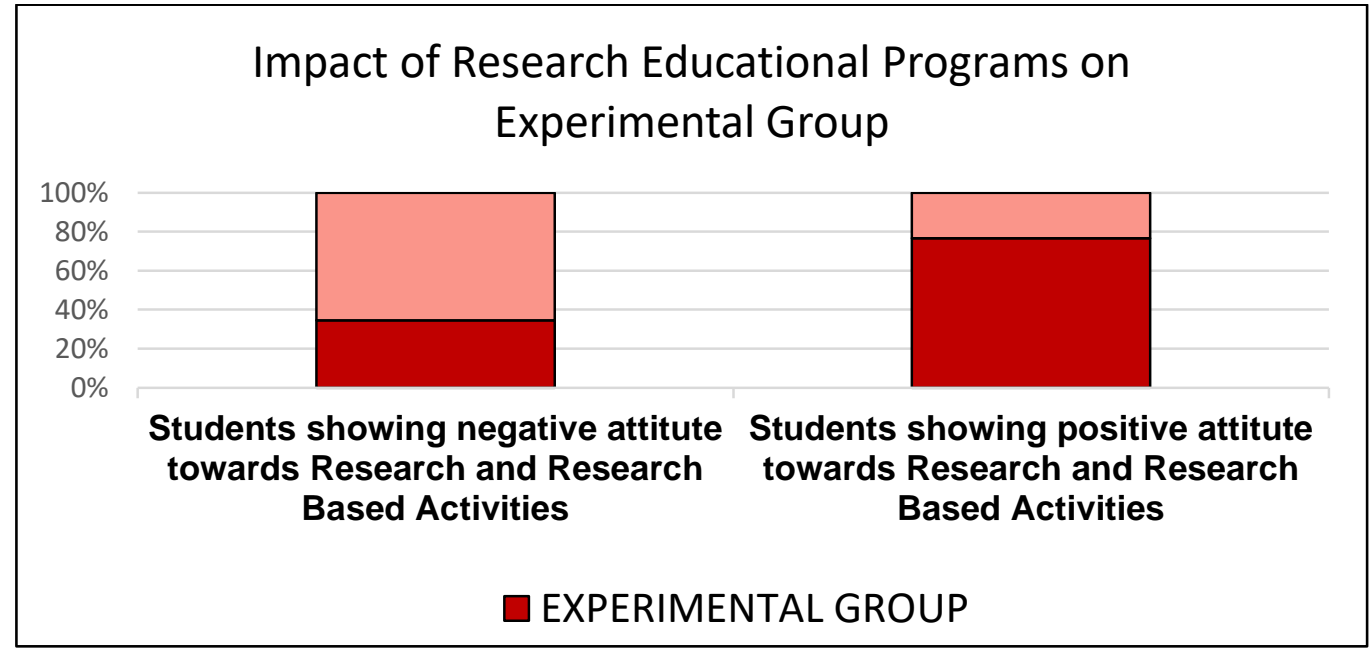

Figure 2. Impact of Research Educational Programs on Experimental Group.

Overall a positive research attitude was seen in the experimental group as compared to the control group, which shows that research educational programs are very effective and play positive role in promoting student's interest towards research.

\section{Discussion}

Research is essential in medical profession as it furnishes proficient guidance and acquisition of latest updates. Although medical institutions encourage their students to carry out research activities in fourth year of medical studies as it is a compulsory part of curriculum, however no guidance or motivation is provided to students in other years. The world is now a global village and the facility of Internet has made it possible for the medical students to access the research work and scholarly articles of other researchers. Digital platforms like ResearchGate, Elsevier, PubMed, JCPSP, MEDLINE, and several 
others are particularly useful for finding different research articles and journals. These web libraries play a key role in research because they make valuable information available. With Google or Google Scholar search engine at hand, medical professionals can scroll through many research articles, in order to make diagnosis of a challenging case (6).

In our study, we found few number of students in Federal Medical \& Dental College, were interested in research and research based studies and considered medical research journal and article reading as boring and waste of time. These findings are similar to research conducted at King Edward medical college, Lahore, which depicted a poor attitude of medical students towards research, seconded by considering this activity useless and a waste of time (6). A similar study conducted on post graduate medical students, in Pakistan Institute of Medical Sciences, Islamabad (7). Our study findings also correlate with similar findings in a study conducted at Khyber Medical College, Peshawar. ${ }^{10}$ This clearly depicts that students need to develop a positive attitude towards research, and this can only be achieved by their proper guidance, motivation and mentorship.

Although majority of our students were well aware of the positive impact of research and its importance in health sciences but they were still hampered due to lack of guidance and mentorship. Similar results have been depicted in a research by Muatasim M Noorelahi, College of Medicine, TU, Madinah, Saudi Arabia, comprising of 223 medical students (third, fourth, and fifth study year). It reported that the most significant obstacles in not conducting research were lack of interest depicted by faculty or guide, along with inadequate facility for research and support by mentors among male students, and lack of motivation and difficulty obtaining approval for the study among female students (11). Whereas Mitwalli et al study included 191 physicians and residents from Riyadh hospital. His study showed that lack of research training $(93.2 \%)$, lack of time $(89.5 \%)$, work-related stress $(83.2 \%)$, and lack of supervisors $(73.3 \%)$ were perceived barriers towards doing research (12). Whereas in our study various barriers identified were lack of motivation $(74.78 \%)$, lack of guidance $(82.74 \%)$, lack of mentorship (72.12\%) and curriculum overload $(69.91 \%)$.
A research conducted at University College Cork (UCC), Cork, Ireland on first, second, third and fourth year medical students showed that a large number of students were completely unaware of the research activities going on in their institution, also students which showed no interest in research strongly believed that researchers are isolated from clinical practice and are detached from the patients, which clearly depicts that students not only lack awareness but have a narrow understanding of the definition and purpose of research (13). These findings agree with our research. In our study we carried out research awareness and guidance programs on our experimental group and they played an important role in increasing their interest towards research in contrast to control group in which awareness remained unchanged. Our study results showed that motivation and research-interest can be generated in students who are properly mentored and guided.

Our study also proposed that in order to increase medical students' knowledge and understanding of research, the teaching of research and research methodology should be made a part of curriculum in all the years of medical school. It is related to a study by Sanjay Kini among third and fourth year MBBS students at KS Hegde medical college, Mangalore which concluded that medical institutions should update their curriculum to include the teaching of research methodology and to allocate specific time for research for all medical students (14). Also, Faisal Al-Nashmy in his study recommended that research methodology and biostatistics should be included as essential subjects in the curriculum of health sciences students and research workshops should be conducted to promote research activities at undergraduate level (15). Nigel Tapiwa Mabvuure in his article has suggested 12 tips for introducing students to research activities and publishing techniques, based on his personal experience and review of the literature (16).

A relative study to ours was conducted at King Abdul-Aziz University, Jeddah by Nahla Khamis R. Ibrahim, with the objective to improve research knowledge among medical students through a research methodology educational intervention course. It showed that the students who received training had significantly higher knowledge score compared to others. Also, a marked improvement was seen in mean knowledge score after research intervention educational program. The study proved 
that intervention program and research training workshop were found to be very successful in improving students' knowledge about research as the participants considered this activity valuable and an enjoyable experience (17). Our study findings also agree with the studies from Croatia (18), Malaysia (19) and India $(20,21)$.

\section{Conclusion}

The knowledge and proper understanding of Research was generally low among medical students. Student's attitude towards Research needs improvement. Important steps should be taken by institutions for offering Research training courses and programs to medical students and by providing Research supervisors and mentors. That would play a key role in apprising them of importance of research at undergraduate and post graduate level. Further studies should be done to explore the reasons why medical students consider research useless and necessary steps should be taken to change this attitude and to bring about behavioral change.

\section{References}

1. Frascati Manual: Guidelines for Collecting and Reporting Data on Research and Experimental Development, The Measurement of Scientific, Technological and Innovation Activities, OECD Publishing, Paris. 2015

2. Hall, S. "Definition of a Research Article." https://penandthepad.com/definition-research-article2711.html. Accessed 28 April 2019.

3. Altman DG. Poor-quality medical research: what can journals do. Jama. 2002 Jun 5;287(21):2765-7.

4. Stevens L, Lynm C, Glass R. Medical Journals. JAMA. 295(15)

5. Booth CC. Medical communication: the old and new. The development of medical journals in Britain. Br Med J (Clin Res Ed). 1982 July 10; 285(6335):105-8.

6. Sheikh, A., Kaleem, A., Waqas, A. and Sheikh, S.: Factors contributing to lack of interest in research among medical students. Advances in Medical Education and Practice.2013: p.237.

7. Saeed I, Khan N, Bari A, Khan R. Factors contributing to the lack of interest in research activities among postgraduate medical students. Pakistan Journal of edical Sciences. 2018; 34(4).

8. Moraes D, Jotz M, Menegazzo W, Menegazzo M, Veloso $S$, Machry $M$ et al. Interest in research among medical students: Challenges for the undergraduate education. Revista da Associação Médica Brasileira. 2016; 62(7):65258 .
9. Alghamdi KM, Moussa NA, Alessa DS, Alothimeen N, Al-Saud AS. Perceptions, attitudes and practices toward research among senior medical students. Saudi Pharm J. 2014; 22(2):113-117.

10. Shahab F, Ali MA, Hussain H. Involvement and barriers to research amongst students of Khyber Medical College. J Postgrad Med Inst. 2013; 27(3):297-302.

11. Noorelahi MM, Soubhanneyaz AA, Kasim KA. Perceptions, barriers, and practices of medical research among students at Taibah College of Medicine, Madinah, Saudi Arabia. Adv Med Educ Pract. 2015; 6:479-85.

12. Mitwalli H, Al Ghamdi K, Moussa N. Perceptions, attitudes, and practices towards research among resident physicians in training in Saudi Arabia. EMHJ. 2014; 20:99-104.

13. Burgoyne LN, O'Flynn S, Boylan GB. Undergraduate medical research: the student perspective. Med Educ Online. 2010; 15.

14. Kini S, Maiya RG, Krishna K N, Udaya Kiran N. Attitudes and perceptions towards research among final year medical students in a private medical college of coastal Karnataka: Across-sectional study. Nitte University Journal of Health Science. 2017 Mar 1;7(1)

15. Al-Shalawy F, Haleem A. Knowledge, Attitudes and Perceived Barriers towards Scientific Research among Undergraduate Health Sciences Students in the Central Province of Saudi Arabia. Education in Medicine Journal. 2015; 7(1):16-21.

16. Mabvuure NT.Twelve tips for introducing students to research and publishing: a medical student's perspective. Med Teach. 2012; 34:705-709.

17. Khamis N, Ibrahim R, Fetyani DM. Assessment of the research-oriented knowledge, attitude and practice of medical students and interns of the King Abdulaziz University, Jeddah and the adoption of a researchintervention educational program. RMJ. 2013;38(4):432439

18. Vujaklija A, Hren D, Sambunjak D, Vodopivec I, Ivanis A, Mausice A,et al. Can teaching research methodology influence students' attitude toward science? Cohort study and nonrandomized trial in a single medical school. J Investig Med2010; 38:282-6.

19. Kyaw Soe HH, Than NN, Lwin H, Nu Htay MNN, Phyu KL, Abas AL. Knowledge, attitudes, and barriers toward research: The perspectives of undergraduate medical and dental students. J Educ Health Promot. 2018; 7:23.

20. Devi V, Abraham RR, Adiga A, Ramnarayan K, Kamath A. Fostering research skills in undergraduate medical students through mentored students projects: example from an Indian medical school. Kathmandu Univ Med J (KUMJ) 2010; 8:294-8.

21. Giri PA, Bangal VB, Phalke DB. Knowledge, Attitude and Practices towards Medical Research amongst the Postgraduate Students of Pravara Institute of Medical Sciences University of Central India. J Family Med Prim Care. 2014; 3(1):22-24 